\title{
Molecular cloning and sequencing of a pectinesterase gene from Pseudomonas solanacearum
}

\author{
ARmin SpöK, Gerhard StUbenRaUCh, Kurt Schörgendorfer $\dagger$ and Helmut SchwaB* \\ Institut für Biotechnologie, Arbeitsgruppe Genetik, Technische Universität Graz, Schlögelgasse 9, A-8010 Graz, Austria
}

(Received 3 July 1990; revised 19 September 1990; accepted 28 September 1990)

\begin{abstract}
Two pectinesterase-positive Escherichia coli clones, differing in expression levels, were isolated from a genomic library of Pseudomonas solanacearum. Both clones contained a common DNA fragment which included the pectinesterase-encoding region. The different expression levels found with the two clones could be ascribed to different positioning of the pectinesterase gene with respect to a vector promoter. Restriction analysis, subcloning, and further exonuclease deletion mapping revealed that the genetic information for pectinesterase was located within a $1.3 \mathrm{~kb}$ fragment. A protein of 41 to $42 \mathrm{kDa}$ was expressed from this fragment. Nucleotide sequence analysis of the respective region disclosed an open reading frame of $1188 \mathrm{bp}$. The deduced polypeptide had a calculated molecular mass of $41004 \mathrm{Da}$, which is consistent with the determined size of the pectinesterase protein. The predicted amino acid sequence showed significant homology to pectinesterases from Erwinia chrysanthemi and tomato. In cultures of $E$. coli clones up to $30 \%$ of total pectinesterase activity was transported into the medium. However, no significant pectinesterase activity could be detected in the periplasm.
\end{abstract}

\section{Introduction}

Pectic enzymes are of great importance as pathogenicity factors in a broad range of plant diseases caused by micro-organisms (Basham \& Bateman, 1975; Stephens \& Wood, 1975; Collmer, 1986). Two main types of pectic enzymes can be distinguished: pectinesterases (PEs), which remove methoxyl residues from pectin, and a variety of depolymerizing enzymes, which cleave the galacturonic acid backbone either by $\beta$-elimination or by hydrolysis. Pectic depolymerases and PEs, in combination with cellulases and proteases, attack the middle lamellae and primary cell walls of plants and may lead to maceration and cell death.

Apart from their role in pathogenesis, pectic enzymes are also of considerable commercial value in the food industry. Crude enzyme preparations, exhibiting different pectinolytic, cellulolytic and proteolytic activities, are used, for example, to clarify fruit juices and to increase the yield of juice and solids from plant material.

$\dagger$ Present address: Biochemie GmbH, A-6250 Kundl, Austria.

Abbreviations: PE, pectinesterase; pme, gene encoding PE; FID, flame ionization detector; CAT, chloramphenicol acetyltransferase.

The nucleotide sequence data reported in this paper have been submitted to GenBank and have been assigned the accession number M37772.
In special cases the use of individual enzymes instead of crude extracts might have some advantages. PE free from depolymerases is of specific interest for preparing low-methoxyl pectin gels (Calesnick et al., 1950) and for the clarification of cider (Rombouts \& Pilnik, 1986). The cloning of various pectate lyase and polygalacturonase encoding genes from Erwinia spp. (Keen et al., 1984; Reverchon et al., 1985; Kotoujansky et al., 1985; Zink \& Chatterjee, 1985), Yersinia pseudotuberculosis (Manulis et al., 1988) and Pseudomonas solanacearum AW (Schell et $a l ., 1988)$ has been described. Plastow (1988) was the first to report the cloning and characterization of a PE gene from Erwinia chrysanthemi B374. Ray et al. (1988) described the identification and sequencing of a cDNA clone from tomato encoding PE.

The occurrence of various types of highly active pectic enzymes has been described for $P$. solanacearum (Lange \& Knösel, 1970; Hildebrand, 1971; Ofuya, 1984), which is one of the most important plant pathogens (Buddenhagen \& Kelman, 1964). Since the objective of our work was the cloning and characterization of genes encoding pectinases of commercial importance, this organism was chosen as a potent source. Here we describe the isolation, subcloning and sequencing of a gene ( $p m e$ ) coding for a PE (EC 3.1.1.11) from the phytopathogenic strain $P$. solanacearum DSM 50905. We also present data on secretion of the PE protein from Escherichia coli clones. 


\section{Methods}

Strains, plasmids and phages. Pseudomonas solanacearum was obtained from the Deutsche Sammlung für Mikroorganismen (DSM 50905). E. coli $\mathrm{HB} 101$ (ATCC 33694) and E. coli C600 (ATCC 23724) were used as hosts for recombinant plasmids. $E$. coli $\mathrm{K} 38$ ( $\mathrm{HfrC}$ ) was used for in vivo analysis of plasmid-encoded proteins. The plasmids pBR322 (Bolivar et al., 1977), pBR325 (Bolivar, 1978) and pUC18 (Yanisch-Perron et al., 1985) were used as vectors for the construction of the gene library and for subcloning experiments. Plasmids pT7-5, pT7-6 and pGP1-2 (Tabor \& Richardson, 1985) were used for the analysis of proteins encoded by cloned DNA fragments. M13mpl 8 and M13mp19 (Norrander et al., 1983) were used to generate singlestranded templates for sequencing reactions.

Cultivation conditions. P. solanacearum and E. coli cells were usually grown in LB medium (Maniatis et al., 1982) at $30^{\circ} \mathrm{C}$ and $37^{\circ} \mathrm{C}$ respectively. For preparation of cell lysates, $\mathrm{M} 9$ mineral salts medium (Miller, 1972), supplemented with the appropriate amino acids (20 $\left.\mathrm{mg} \mathrm{l}^{-1}\right)$ and thiamin $\left(2 \mathrm{mg} \mathrm{l}^{-1}\right)$, and containing glycerol $\left(5 \mathrm{~g} \mathrm{l}^{-1}\right)$ as the sole carbon source, was used. For the selection of plasmids, ampicillin $\left(100 \mathrm{mg} \mathrm{l}^{-1}\right)$, tetracycline $\left(10 \mathrm{mg} \mathrm{l}^{-1}\right)$ and kanamycin (40 $\left.\mathrm{mg} \mathrm{l}^{-1}\right)$ were added as required.

DNA isolation. High-molecular-mass chromosomal DNA of $P$. solanacearum was isolated by the method of Saito \& Miura (1963). Large-scale preparations of plasmid DNA were done by the alkaline lysis method, with further purification by caesium chloride/ethidium bromide gradient centrifugation (Maniatis et al., 1982). The method of Birnboim \& Doly (1979) was used for small-scale extractions and rapid analysis of plasmid DNA.

Construction of a gene library of $P$. solanacearum. Chromosomal DNA was partially digested with Sau3AI and fractionated by agarose gel electrophoresis. Fragments $5-15 \mathrm{~kb}$ in size were recovered by electroelution (Maniatis et al., 1982) and purified by DEAE-cellulose chromatography using Whatman DE52. The purified fragments were ligated into BamHI-cleaved, dephosphorylated pBR322. The ligation mixture was used to transform E. coli $\mathrm{HB} 101$. Recombinant clones containing inserts were detected by their $A p^{R} / \mathrm{Tc}^{\mathrm{S}}$ phenotypes.

General recombinant DNA techniques. Restriction endonucleases and DNA-modifying enzymes were used under the conditions recommended by their suppliers. All cloning procedures as well as BAL31 digestions and modifications of DNA fragments were performed according to standard methods as described by Maniatis et al. (1982). Unphosphorylated XhoI-linkers (8-mer, Pharmacia) were used to religate plasmids following BAL31 deletion as described by Seth (1984). Specific DNA fragments were recovered from agarose gels by electroelution as described by Maniatis et al. (1982) or by electrotransfer onto NA45-DEAE-membranes (Schleicher \& Schuell). In the case of small DNA fragments the 'freeze-squeeze' method of Thuring et al. (1975) was used.

Screening. The screening for pectinolytic clones was performed by a method based upon the 'cup-plate' assay of Dingle et al. (1953). Recombinant $E$. coli clones were grown for 2-3 d on M9-glycerol agar plates supplemented with $5 \mathrm{~g}$ pectin $\mathrm{l}^{-1}$ (Sigma P-9135). The plates were then flooded with a saturated solution of copper acetate. Clear zones ('haloes') on a turbid background appear around colonies expressing pectinolytic activities.

Preparation of cell extracts. E. coli cells were grown in M9-glycerol medium to the late exponential growth phase and harvested by centrifugation. The cells were suspended in fresh, ice-cold $\mathbf{M} 9$ medium and disrupted by ultrasonication (B. Braun Labsonic 2000, $100 \mathrm{~W}$, $2 \times 30 \mathrm{~s}$ ). The cell lysates were centrifuged for $20 \mathrm{~min}$ at $30000 \mathrm{~g}$ to remove cell debris. Extracts were stored at $4{ }^{\circ} \mathrm{C}$. The protein content was determined by the Lowry method.

Preparation of cell fractions. E. coli clones were grown in M9-glycerol medium to the stationary phase, and the cells were harvested by centrifugation. After removal of the supernatant, portions of $1.0 \mathrm{~g}$ (wet weight) of the pelleted cells were resuspended in $80 \mathrm{ml} 30 \mathrm{~mm}$-Tris $(\mathrm{pH} 7 \cdot 3) / 20 \%(\mathrm{w} / \mathrm{v})$ sucrose. EDTA was added to a final concentration of $10^{-3} \mathrm{M}$, and the suspension was incubated with vigorous shaking (rotary shaker, 180 r.p.m.) for $7 \mathrm{~min}$ at room temperature. After centrifugation the Tris/sucrose/EDTA supernatant (TSE) was collected. For preparing the fraction containing the periplasmic enzymes the 'osmotic shock' method of Heppel (1971) was followed. The cytoplasmic fraction was obtained by ultrasonic treatment of the remaining spheroplasts and removal of cell debris. Protein was determined according to Bradford (1976) using a commercial reagent kit (BioRad).

Detection of enzyme activities. PE activity was assayed by determination of liberated methanol by gas chromatography (GC). Cell lysates were diluted with $50 \mathrm{~mm}$-Tris/ $\mathrm{HCl} \mathrm{pH} 7.0$ as appropriate. For control experiments the lysates were replaced by $\mathrm{M} 9$ medium or a solution of a commercial PE (Sigma P-1889). The reaction assay was set up by mixing $900 \mu \mathrm{l}$ of a pectin stock solution $\left(10 \mathrm{~g} \mathrm{l}^{-1}\right)$ and $900 \mu \mathrm{l}$ of diluted cell lysates in sterile sealable glass vials (Wheaton). After accurate sealing, the vials were incubated at $30^{\circ} \mathrm{C}$. Samples of $0 \cdot 8 \mu \mathrm{l}$ were taken at appropriate time intervals and injected into the gas chromatograph. The following conditions were used for GC analysis: glass column $(1.8 \mathrm{~m} \times 2 \mathrm{~mm})$ containing Poropak Q (80-100 mesh), column temperature $160^{\circ} \mathrm{C}$, injector temperature $170^{\circ} \mathrm{C}$, FID temperature $210^{\circ} \mathrm{C}$, carrier gas nitrogen, $30 \mathrm{ml} \mathrm{min}^{-1}$. One unit of PE is defined as $1 \mu \mathrm{mol}$ methanol liberated $\min ^{-1}$ at $30^{\circ} \mathrm{C}$.

Depolymerase activity was determined by HPLC analysis of reaction products using the following conditions: Aminex resin-based column (BioRad $\mathrm{HPX}-87 \mathrm{H}$ ), $300 \times 7.8 \mathrm{~mm}$, column temperature

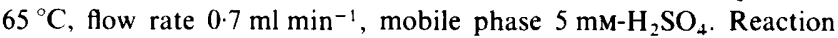
assays were prepared in standard reaction tubes using pectin and pectate (Sigma P-1879) as substrates. Equal volumes $(500 \mu \mathrm{l})$ of a substrate stock solution $\left(10 \mathrm{~g} \mathrm{l}^{-1}\right)$ and cell-free extract were mixed in Eppendorf tubes and incubated at $30^{\circ} \mathrm{C}$ for various times up to $8 \mathrm{~h}$. Reactions were stopped by heating to $95^{\circ} \mathrm{C}$ for $3 \mathrm{~min}$. Solids were removed by centrifugation, and samples of the supernatants were injected in to the HPLC. Two commercial pectic depolymerases (Sigma P-5146, P-3026) were used in control experiments.

Chloramphenicol acetyltransferase activity was measured according to Shaw (1975) by following the formation of 5-thio-2-nitrobenzoate photometrically at $412 \mathrm{~nm}$.

Activities of $\beta$-lactamase were estimated using the chromophoric substrate nitrocefin and monitoring spectrophotometrically the increase of absorbance at $482 \mathrm{~nm}$ as described by O'Callaghan et al. (1972).

Analysis of encoded proteins. A T7 R NA polymerase/promoter system was used for specific labelling of plasmid-encoded proteins (Tabor \& Richardson, 1985). DNA fragments were cloned into the vector plasmids pT7-5 and pT7-6 downstream of the bacteriophage T7 $\phi 10$ promoter. These two plasmids differ in the orientation of their multiple cloning sites, and DNA fragments can therefore be cloned and analysed in both orientations. The recombinant plasmids were used to transform E. coli K38 harbouring plasmid pGP1-2; this plasmid contains the gene for T7 RNA polymerase under the control of the $\lambda \mathrm{P}_{\mathrm{L}}$ promoter, which is regulated by the thermosensitive repressor $c I 857$. After a period of normal cell growth at $30^{\circ} \mathrm{C}$, the transcription of the T7 RNA polymerase gene was induced by a temperature shift to $42{ }^{\circ} \mathrm{C}$. The host RNA polymerase was inhibited by additon of rifampicin, and translated polypeptides were labelled with $\left[{ }^{35} S\right]$ methionine. Sub- 
sequently, cells were lysed, and synthesized polypeptides were analysed by SDS-PAGE (Laemmli, 1970) and fluorography.

DNA sequencing. Single-stranded DNA templates were obtained by cloning deletion fragments into M13 derivatives $\mathrm{mp} 18$ and $\mathrm{mp} 19$, and sequencing was performed according to the dideoxy chain-termination method (Sanger et al., 1977) using $\left[\alpha^{-35}\right] \mathrm{dATP}\left(400 \mathrm{Ci} \mathrm{mmol}^{-1}\right.$; 14.8 $\mathrm{TBq} \mathrm{m^{-1 }}{ }^{-1}$ ) and T7 DNA polymerase (Sequenase, USB). To overcome secondary structures in G + C-rich stretches, 7-deaza-dGTP or dITP were used alternatively in the sequencing reactions.

Sequence data were handled and analysed using the 'Gene Master' (BioRad) or GCG (Genetics Computer Group, University of Wisconsin) computer program packages.

Construction of $p G S T l$. The $2.0 \mathrm{~kb}$ EcoRV fragment of pSAP1 3 was ligated with EcoRV-cleaved, dephosphorylated pBR325. Hybrid plasmids which contained the pme gene fragment in the proper orientation (under the control of the vector $\mathrm{P} 2$ promoter) were selected and designated as pGST1.

\section{Results and Discussion}

\section{Cloning of the pme gene}

A genomic library of $P$. solanacearum was prepared in $E$. coli HB101 using pBR322 as vector plasmid. Seven thousand $E$. coli clones were individually tested for pectinolytic activities using the pectin agar plate assay. Two putative clones showing a significant difference in the size of the produced haloes were found. The hybrid plasmids contained in these clones were designated as pSAP1 (6.1 kb insert; ]arger halo) and pSAP2 (10.5 kb insert; smaller halo). B retransformation of $E$. coli $\mathrm{C} 600$ with isolated plasmid DNA it was verified that pectinolytic activity was mediated by the respective plasmids.

Cell extracts of $E$. coli $\mathrm{C} 600$ clones harbouring pSAP1, pSAP2 or pBR322 were prepared and assayed for PE and pectic depolymerase activities by GC and HPLC analysis. No significant depolymerase activity on pectin or pectate could be detected under the conditions used. In tests for PE activity, methanol was liberated from pectin in reaction mixtures containing cell lysates of pSAP1 and pSAP2 clones. Control experiments with lysates of E. coli $\mathrm{C} 600$ (pBR322) showed detectable but very low levels of liberated methanol, and similar effects were seen when cell lysates were replaced with M9 medium. Since methyl ester groups are very sensitive to saponification by dilute alkali, even at low temperature (Albersheim et al., 1960), this slight background of methanol could be due to such effects. In accordance with the observation that pSAP1 clones produced larger haloes on pectin agar plates, a much higher specific activity of PE (about 14-fold) was found in the lysates of pSAP1 clones compared to pSAP2 clones (Fig. 1).

Restriction enzyme analysis and Southern blot hybridization experiments using PSAP1 and pSAP2 DNA

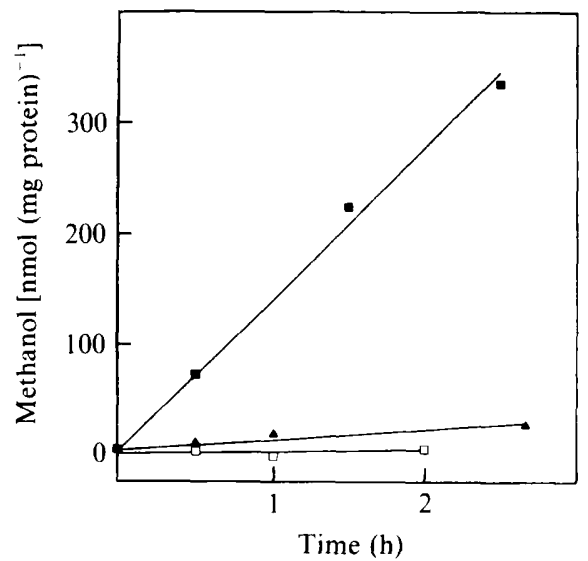

Fig. 1. PE activity in cell extracts of different $E$. coli clones. Cell extracts were prepared, and PE activity was determined by GC as described in Methods. The increase of liberated methanol as a function of incubation time is shown for $E$. coli C600 containing pSAP1 ( $\boldsymbol{\square}$ ), pSAP2 (A) or (control) pBR322 ( $\square$ ). The data are based on the content of total protein in the lysates.

showed partial identity between these plasmids, suggesting that they contain overlapping fragments of $P$. solanacearum DNA. The orientation of this common fragment is different with respect to the pBR322 vector part. A deletion derivative of pSAP12 (see Fig. 2) lacking the P2 promoter of the pBR322 vector part (pSAP121) exhibited a decrease in PE activity to the level of pSAP2 clones (data not shown). This indicates that the high level of expression of PE in clones containing pSAPI, pSAP11, pSAP12 and pSAP13 (Fig. 2) could be mediated by transcription of the pme gene from the P2 promoter of pBR322, whereas in pSAP2 and in pSAP121 a $P$. solanacearum promoter which can be recognized by $E$. coli RNA polymerase seems to be active. These data also provided evidence for the direction of transcription of the pme gene as indicated in Fig. 2.

\section{A $1.34 \mathrm{~kb}$ fragment contains the entire information for $P E$}

Based upon detailed restriction analysis, various subfragments of pSAP1 were cloned into pBR322 or pUC18. The clones obtained were investigated for their ability to express PE activity. The smallest fragment still conferring the PE phenotype upon $E$. coli clones was identified in pSAP13 (Fig. 2). pSAP13 was constructed by introducing a $2.0 \mathrm{~kb}$ ClaI fragment of pSAP 1 , containing the $0.3 \mathrm{~kb}$ ClaI-BamHI fragment of pBR322 and the $1.7 \mathrm{~kb}$ Sau $3 \mathrm{AI}-C l a \mathrm{I}$ fragment of $P$. solanacearum DNA, into the ClaI site of pBR322. With respect to the pBR322 vector part, the orientation of the cloned fragment in pSAP13 is analogous to pSAP1. 


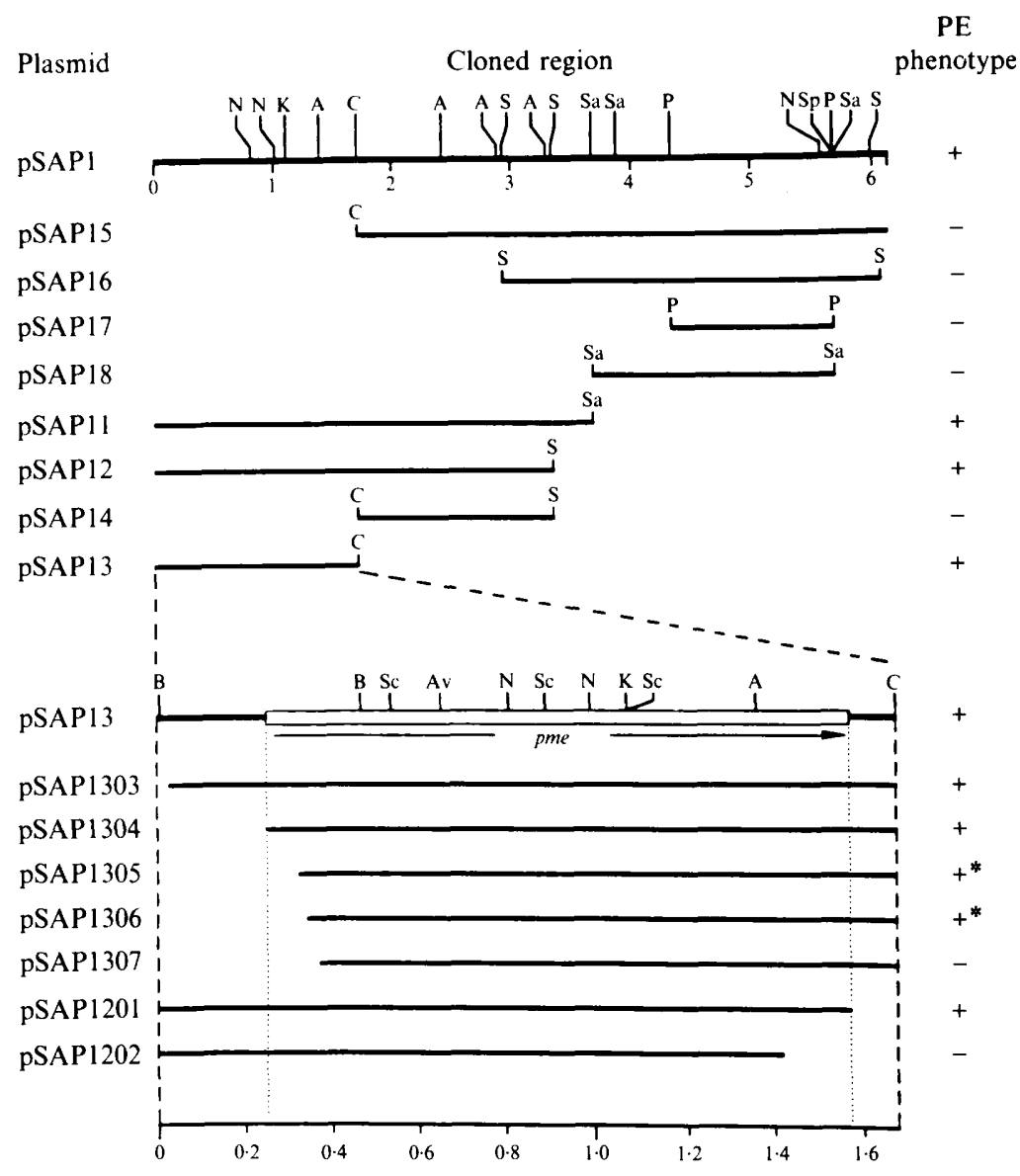

Fig. 2. Restriction map of the $P$. solanacearum DNA fragment in pSAPI and locations of cloned subfragments. The plasmids pSAP11, pSAP12 and pSAP15 resulted from deletion of certain fragments of pSAP1 and subsequent religation. pSAP13, pSAP14, pSAP16, pSAP17 and pSAP18 were constructed by subcloning restriction fragments into the vector plasmids pUC18 or pBR322. A detailed restriction map of the $1.7 \mathrm{~kb}$ fragment of pSAP13 and positions of relevant exonuclease BAL31 deletions are shown in the lower part of the figure. The strategy for deletions at the 5' end (pSAP1303-1307) was as follows. pSAP13 DNA was linearized with EcoRI. After incubation with BAL31 the DNA was digested with HindIII. Appropriate fragments were ligated into SmaI/HindIII-cut pUC18. For 3' deletions (pSAP1201-1202), pSAP12 was partially digested with ClaI. Following incubation with BAL31, the resulting fragments were religated by attachment of a $X$ ho-linker. All recombinants were used to transform E. coli $\mathrm{HB} 101$ and assayed on pectin agar plates. The ability to express a functional PE is shown in the right-hand column. $\left({ }^{*} E\right.$. coli clones harbouring pSAP1305 or pSAP1306 exhibited less PE activity on pectin agar plates than did other PE-positive clones. For details see text.) The region encoding the PE is represented by an open bar. Direction of transcription of the pme gene is indicated by an arrow. Restriction sites are indicated for: A, ApaI; Av, AvaI ; B, BamHI ; C, ClaI ; K, KpnI ; N, NcoI ; P, PstI; Sc, SacII; S, SalI ; Sa, SmaI ; Sp, SphI. Sizes are given in $\mathbf{k b}$.

Exonuclease BAL31 deletions were carried out from both ends of the $1.7 \mathrm{~kb}$ fragment. A set of clones selected after restriction analysis was assayed for PE activity. The results presented in Fig. 2 show that the removal of up to $0.26 \mathrm{~kb}$ at the $5^{\prime}$ terminus (pSAP1303-1304) and of approximately $0.1 \mathrm{~kb}$ at the $3^{\prime}$ end (pSAP1201) did not influence the expression of $\mathrm{PE}$ activity. Cells harbouring pSAP1305 or pSAP1306, carrying $5^{\prime}$ deletions of about $0.33 \mathrm{~kb}$ and $0.34 \mathrm{~kb}$ respectively, exhibited a markedly lower PE activity on pectin agar plates. The further deletion of a small part at the $5^{\prime}$ end (pSAP1307) or at the $3^{\prime}$ terminus (pSAP1202) resulted in a complete loss of PE activity.

From these data it was concluded that the entire pme gene is located within a $1.34 \mathrm{~kb}$ fragment as indicated in Fig. 2. Furthermore, it is probable that the decreased PE activity in clones containing pSAP1305 or pSAP1306 is due to an effect on the promoter region.

\section{Identification of the PE polypeptide}

Proteins encoded by the $1.7 \mathrm{~kb}$ fragment of pSAP13 were analysed by expression studies using the T7 RNA polymerase/promoter system. The pme region was prepared as a $1.9 \mathrm{~kb}$ fragment using the $E c o \mathrm{RV}$ and HindIII vector sites of pSAP13 and ligated into the SmaI/HindIII-digested plasmids pT7-5 and pT7-6 as shown in Fig. 3(a). The resulting hybrids were used to transform E. coli $\mathrm{K} 38$ harbouring pGP1-2 and the plasmid-encoded proteins were labelled as described in Methods. After fluorography of the SDS-polyacrylamide gel a single protein band could be detected with pSAP132 but not with pSAP133 (Fig. $3 b$ ). This protein, which we conclude to represent $\mathrm{PE}$, has a molecular mass of about $42 \mathrm{kDa}$ and was only expressed when the PE-encoding region was transcribed in the direction expected for transcription from the natural promoter. A plasmidspecific $41 \mathrm{kDa}$ protein was also detected by SDS-PAGE analysis of total proteins present in cell lysates and culture supernatants of $E$. coli clones containing pSAP1 (results not shown).

\section{Nucleotide sequence of the pme gene}

The nucleotide sequence of the 1698 bp Sau3AI-ClaI fragment present in pSAP13 is given in Fig. 4. An open reading frame extending from the methionine codon (ATG) at position 287 to the termination codon at 
(a)
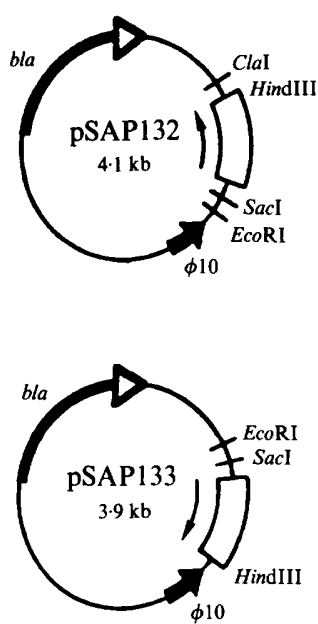

Fig. 3. Detection of polypeptides encoded by the $P$. solanacearum DNA insert of pSAP13. (a) Hybrid plasmids constructed for expression mediated by T7 RNA polymerase. The PE-encoding region of pSAP13 was prepared as an EcoRV-HindIII fragment and ligated into SmaI/HindIII-cut pT7-5 and pT7-6 and is represented by the doublelined segment; the direction of transcription of the pme gene is indicated by the small arrow. The bacteriophage $\mathrm{T} 7 \phi 10$ promoter and the gene coding for $\beta$-lactamase (bla) are also indicated. (b) Analysis of encoded proteins by SDS-PAGE and fluorography. Lane 1, pT7-5. Lane 2, pSAP133. Lane 3, pSAP132. The positions of unlabelled molecular mass marker proteins are shown on the left. From top to bottom: phosphorylase $b$, bovine serum albumin, ovalbumin, carbonic anhydrase. The arrow indicates the $42 \mathrm{kDa}$ band in lane 3 which is absent if the direction of transcription is reversed (lane 2 ).

position 1475 was found which could encode a protein of 396 amino acids and a calculated molecular mass of $41004 \mathrm{Da}$. This fits well to the size of the identified polypeptide $(41-42 \mathrm{kDa})$. A putative Shine-Dalgarno sequence $(S / D$; indicated in Fig. 4) can be found appropriately positioned $5^{\prime}$ to the presumed translational start codon. The additional ATG found in the same reading frame at position 434 is not preceded by a reliable $S / D$ sequence.

The $\mathrm{G}+\mathrm{C}$ content of the pme gene was $65 \mathrm{~mol} \%$ and corresponds to the overall $\mathrm{G}+\mathrm{C}$ content of $66-67 \mathrm{~mol} \%$ specified for the $P$. solanacearum chromosome (Holloway \& Morgan, 1986). As with other Pseudomonas genes (Hadero \& Crawford, 1986), the high $\mathrm{G}+\mathrm{C}$ content could be attributed to a bias towards $\mathrm{G}$ and $\mathrm{C}$ nucleotides in the third position $(88.2 \%)$. Furthermore, the restricted codon usage ( 46 of 61 codons are utilized; data notshown) resembles that of highly expressed genes in $E$. coli.

Computer analysis of the $5^{\prime}$ non-coding region disclosed several putative promoters homologous to $E$. coli $\sigma^{70}$ consensus sequences as indicated in Fig. 4. Analogous promoter structures have also been described for Pseudomonas spp. (Deretic et al., 1989). The sequence from bases 82 to 110 , for instance, shows $67 \%$ homology with the -35 and -10 sequences of the $\sigma^{70}$ consensus promoter. The spacing between the -35 and -10 regions is 16 bases, which is typical for strong $E$. coli promoters (Hawley \& McClure, 1983). In addition, as described by Drew et al. (1985) for Gram-negative bacteria, an A+T-rich region was observed around this putative pme promoter. The $\mathrm{A}+\mathrm{T}$ content of the promoter-flanking region from bases 80 to 160 is $54 \mathrm{~mol} \%$, whereas the overall $\mathrm{A}+\mathrm{T}$ content for the pme gene is $35 \mathrm{~mol} \%$.

Downstream of the translational stop of pme, two inverted repeats which may form stem-loop structures $(1500-1540,1566-1588)$ can be seen. However, these repeats are not followed by $\mathrm{T}$ residues, and it is not clear whether these structures could represent transcriptional terminators.

\section{Homologies between PEs}

The primary structures of the PEs from Erwinia chrysanthemi (Plastow, 1988) and tomato (Lycopersicon esculentum; Ray et al., 1988) have been reported. Both proteins are similar to the $P$. solanacearum enzyme with respect to their size, 366 and 390 amino acids, and their calculated subunit molecular mass, 39318 and $42506 \mathrm{Da}$, respectively.

By carrying out individual alignments of the deduced amino acid sequences of these proteins, the percentage of overall identity was calculated according to the algorithm of Needleman \& Wunsch (1970). The homology between the two bacterial PEs was determined to be about $30 \%$. Surprisingly, the homology between the bacterial enzymes and the tomato PE was in the same range. The highest homology score was found between the E. chrysanthemi $\mathrm{PE}$ and the tomato $\mathrm{PE}$, about $32 \%$ identity, which corresponds to data published recently by Hinton et al. (1990). Good homologies were also identified between the deduced amino acid sequences of a tomato polygalacturonase and two bacterial polygalacturonases, the $p g l A$ gene product of $P$. solanacearum AW (Huang \& Schell, 1990), and the peh gene product of Erwinia carotovora (Hinton et al., 1990).

A three-way comparison between the amino acid sequences of all three PE polypeptides is shown in Fig. 5. Short stretches of highly conserved amino acids occur at several positions. Since some of these regions are well conserved in the prokaryotic and the eukaryotic enzymes, an implication of essential structures (enzymically active sites) of the PE molecules may be considered. However, biochemical indications about functional domains in PEs have not been experimentally determined. In Fig. 6 the relative spacings of the well- 
Sausn I

GATCCGC ACG ATG GAA AAA CTG ACG CCC GCT TGC CCG GAC ATC GGC CAT CCG GCT tGT AGA CGG AAG ACC ACC CGC ATA TAT TGC CGA AGC GCT TTT GAA CGA TTA TCA AAG TTG AAT CGG CAA TAA TCG TGC GCG CAA TCC GGT CCA AAT GAA CGC GAT CCT TAT AAT GGC GCT CCC GGC CAA TGT CCG OGC AGC GCC GCC CAA TTC CAT CAG TTG CAT ATT CCT CTA AAA AAC AAA ACC GCC TGA CAT CGg ATC AGG CCT GCC TTT GAC AGG AAA AAT CGA CAC ATG CAA TCA ACA ThE Leu Tyr Leu Lys Thr Ala Ala Phe Leu Gly Gly Cys Ser Leu Phe Ala Ala Thr Ala Leu

Ala Ala Thr Ser Thr Ala Thr Arg Pro Gln Leu Ser Asn Ala Asp Ala Arg Ala Tyr Thr GCC GCG ACC AGC ACC GCC ACA CGC CCG CAA CIC AGC AAC GCC GAC GCA CGE GCC TAT ACG

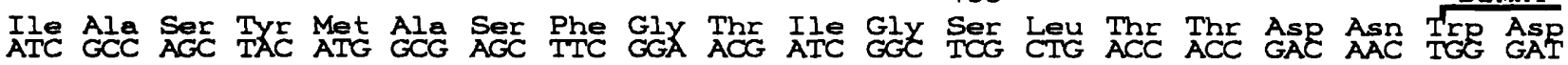
Pro Thr Gly Gly Val Gly Ala Val Ser Gly Phe Arg Ala Asn Tyr Ala Val Ala Ala Asp Gly Ser Ala GIn Tyr Lys Thr Val Gin Ala Ala Ile Asp Ala Ala Val Ala Asp Gly Gly Val Val Ala Arg LYs Tyr Ile Ser Val Lys Ala Gly Thr Tyr Asn Glu Leu Val Cys Val Pro nual

Glu Ser Ala Pro Pro Ile Thr Leu Tyr Ser Leu Asp Ala Asn Ala Asn Asn Thr Val Ile GAG TCG GCG CCC CCC ATC ACG CTG TAT AGC CTC GAT GCC AAC GCC AAC AAC ACG GTG ATC

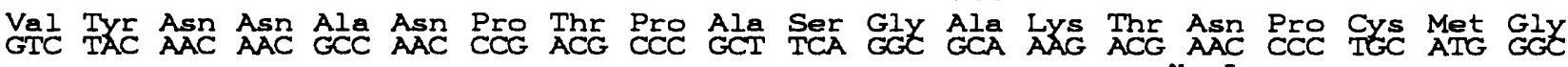
Thr Ser Ser Asn Ala Thr Val Gly Thr Val Arg Ser Ala Thr Ala Met Val Arg Ala Ser
ACC AGC AGC AAC GCG ACG GTC GGC ACG GTG CGC AGC GCC ACC GCC ATG GTG CGG GCA TCG

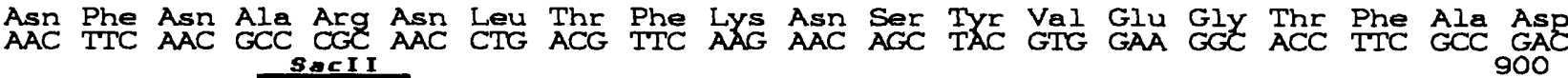
Asn Asn Gin Ser Ala Val Ala Leu Ala Val Arg Gly Asp Lys Ala Ile Leu Glu Asn Val AAC AAC CAG TCC GCG GTG GCG CTT GCC GTG CGC GGC GAC AAG GCG ATC CTC GAA AAC GTC Ser Val Ile Gly Asn Gln Asp Thr Leu Tyr Leu Gly Ala Thr Asn Asn Thr Met Val Ile TCG GTC ATC GGC AAC CAG GAC ACG CTG TAT CTC GGC GCG ACG AAC AAC ACC ATG GTG ATC

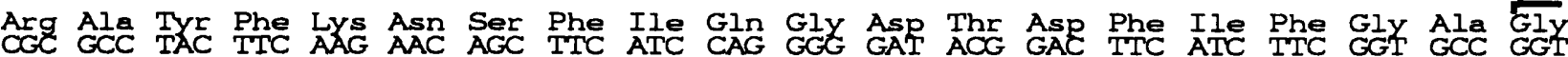
Thr Ala Val Phe His Gly Cys Thr Ile Gln Tyr Thr Ala Ala Arg Leu Gly Ala Arg Ala Thr Ala Val Phe His Gly Cys Thr Ile Gln Tyr Thr Ala Ala Arg Leu Gly Ala Arg Ala The Ser Tyr Val Phe Ala Pro Ser Thr Ala Pro Asp Asn Pro His Gly Phe Leu Ala Ile

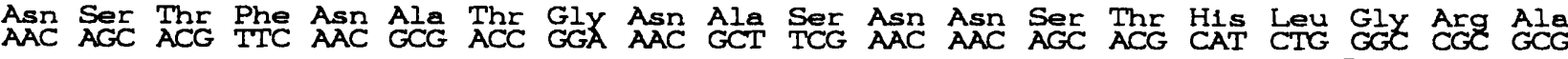
Trp Asp Gln Gly Val Ser Gly Thr Ser Ala Tyr Ile Asn Gly Ser Ser Pro Asn Gly Gln IGE GAI CAG GGC GTG AGC GGE ACG TCG GCC TAT ATC AAC GGC AGT TCG CCC AAC GGG CAG Val Val Ile Arg Asp Ser Ser Leu Gly Ala His Ile Arg Leu Ala Asp Pro Trp Gly Pro

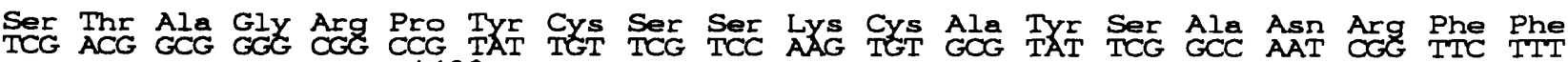
1400

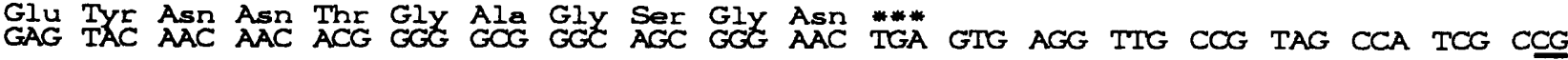
GGA TGG GCC GCC CCT TGC AGG GGG CAT CGG CCC ATC CTG CCC GAT GAT CCG GCC GGG ATC TCA AGC GCG CTT TCT GGT GAA GCG OGC GGA ACG CTC CCC CGA AGG CTG GCT CAT CGT CTC CTG ATT CAT CCG GTC GAG CAC ACG CTT GGC CCG GTC CGT GCA ATC TTC GCC TTC CGC CTI GGT OGC AGC TCA TCG AT 


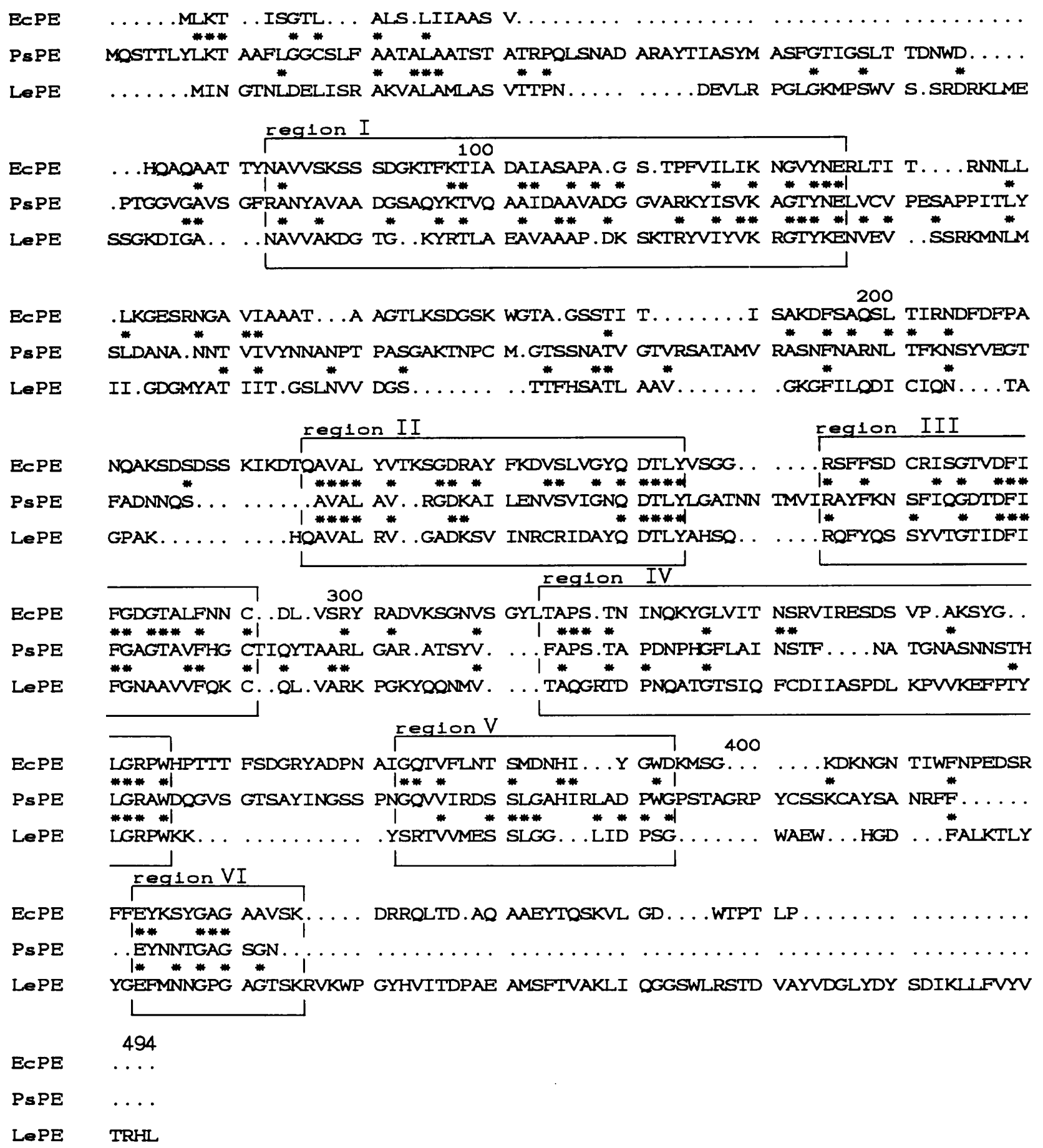

Fig. 5. Comparison of the deduced amino acid sequences of the PEs of P. solanacearum (PsPE), E. chrysanthemi (EcPE; Plastow, 1988) and $L$. esculentum (LePE; Ray et al., 1988). Identical residues are indicated by asterisks. Regions of high homology are boxed and numbered (I to VI).

Fig. 4. Nucleotide sequence of the $1.7 \mathrm{~kb}$ Sau3AI-ClaI P. solanacearum DNA fragment containing the pme coding region. Nucleotides are numbered starting from the Sau $3 \mathrm{AI}$ site at the top. A Shine-Dalgarno (S/D) box and regions showing homology to the -35 and -10 consensus of $E$. coli $\sigma^{70}$ promoters are indicated. The stop codon is marked by three asterisks. Palindromic sequences in the $3^{\prime}$ noncoding region are indicated by arrows. The deduced amino acid sequence is shown along with selected endonuclease restriction sites. 


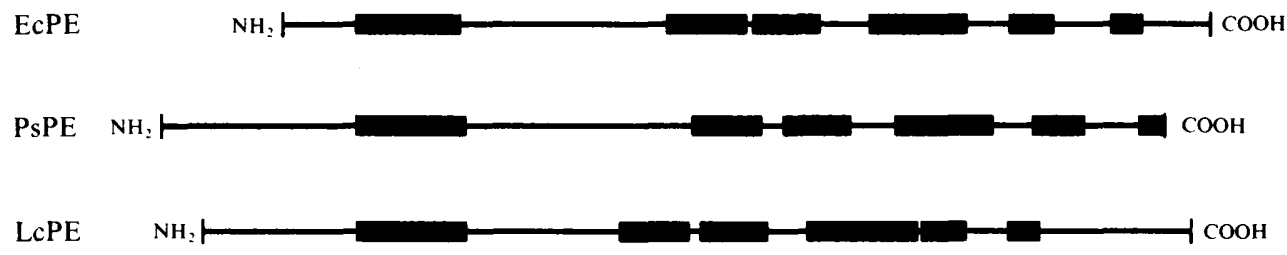

100

amino acids

Fig. 6. Relative positions of the highly homologous regions derived from a three-way comparison of the amino acid sequences shown in Fig. 5. Sizes and relative positions of regions I to VI and the amino- and carboxy-termini of each PE enzyme are indicated.

Table 1. Relative distribution of enzyme activities in subcellular fractions of E. coli cells

Stationary E. coli cultures were fractionated and assayed for PE, $\beta$-lactamase and CAT activity as described in Methods. Enzyme activities are expressed as a percentage of the total activity of the culture. Sup., supernatant; TSE, Tris/sucrose/EDTA fraction; Per., periplasmic fraction; Cyt., cytoplasmic fraction; ND, not detectable.

\begin{tabular}{|c|c|c|c|c|c|c|c|c|c|c|c|c|}
\hline & \multicolumn{4}{|c|}{ PE } & \multicolumn{4}{|c|}{$\beta$-Lactamase } & \multicolumn{4}{|c|}{ CAT } \\
\hline & Sup. & TSE & Per. & Cyt. & Sup. & TSE & Per. & Cyt. & Sup. & TSE & Per. & Cyt. \\
\hline E. coli $\mathrm{C} 600(\mathrm{pGST} 1)$ & $17 \cdot 6$ & 1.0 & ND & $81 \cdot 4$ & 35.9 & $2 \cdot 9$ & $54 \cdot 3$ & 6.9 & $0 \cdot 2$ & 1.5 & 0.2 & $98 \cdot 1$ \\
\hline E. coli $\mathrm{C} 600$ (pSAP1) & $30 \cdot 1$ & $1 \cdot 2$ & ND & $68 \cdot 7$ & $35 \cdot 3$ & $4 \cdot 2$ & $56 \cdot 9$ & 3.6 & - & - & - & - \\
\hline E. coli $\mathrm{C} 600(\mathrm{pBR} 325)$ & - & - & - & - & 28.9 & $1 \cdot 3$ & $57 \cdot 1$ & $12 \cdot 7$ & $0 \cdot 1$ & $0 \cdot 3$ & $0 \cdot 1$ & $99 \cdot 5$ \\
\hline
\end{tabular}

conserved regions are compared. It is apparent that the relative positions of all conserved regions are very similar with the bacterial PE enzymes but less stringent with the tomato enzyme. Nevertheless, the spacings of the internal regions from III to IV (21-24 amino acids), and of the carboxy-terminal regions from V to VI (19-23 amino acids) respectively, seem to be well conserved in all the proteins.

\section{Localization of PE activity in E. coli clones}

The ability of $E$. coli clones to degrade pectin on pectin agar plates indicated that PE is present extracellularly. To distinguish between partial leakage, cell lysis and active secretion, we performed a more extensive analysis of the compartmentalization of PE in E. coli. For this purpose pGST1 was constructed. This plasmid contains the pme gene as well as the genes for $\beta$-lactamase and chloramphenicol acetyltransferase (CAT) as periplasmic and intracellular marker enzymes. E. coli clones harbouring pGST1, pSAP1 and pBR325 were grown in glycerol medium to the stationary phase $\left(\mathrm{OD}_{550}=2.0\right)$ and fractionated as described in Methods. All fractions were assayed for PE activity and for activities of the marker enzymes $\beta$-lactamase (periplasmic) and CAT (cytoplasmic). The results are summarized in Table 1. Almost all of the CAT activity remained in the cytoplasm, indicating that cell lysis does not occur. However, the detection of a significant amount of $\beta$-lactamase activity in the supernatants of all $E$. coli clones investigated provides evidence for (PE-independent) periplasmic leakage. PE activity was mainly found in the cytoplasm and in the supernatant, whereas no PE activity could be detected in the periplasm.

Periplasmic leakage has often been described for extracellular enzymes, e.g. Erwinia pectinases, which have been cloned and expressed in Escherichia coli. Due to correct recognition and processing of a functional signal peptide by the $E$. coli secretion system the majority of the enzyme accumulates in the periplasmic space and is further released, together with periplasmic marker enzymes, into the medium (Keen et al., 1984; Collmer et al., 1985). SDS-PAGE of cell lysates and culture supernatants of PE-positive E. coli clones and experiments using the $\mathrm{T} 7$ in vivo-labelling system provided no evidence that processing of the PE protein occurs in $E$. coli cells. In accordance with these observations the first few residues of the predicted amino acid sequence do not 
comply with the 'minimal requirements' for signal peptides postulated by Von Heijne (1985).

Considering our results, the appearance of larger amounts of PE activity in culture supernatants could not be attributed to simple outer-membrane leakage. The lack of PE activity in the periplasmic fraction might indicate a different mechanism for transporting PE out of the cell. As the secretion of the PE protein would be a desired option for its biotechnological production, further investigations on overproduction and secretion of the PE are in progress.

We would like to thank Dr Stan Tabor for providing the T7 polymerase/promoter system and Susanne Hainzl for technical assistance.

This work was supported by the Austrian Bundesministerium für Wissenschaft und Forschung.

\section{References}

Albersheim, P., Neukom, H. \& Deuel, H. (1960). Formation of unsaturated dehydration products by a pectin degrading enzyme. Helvetica Chimica Acta 43, 1422-1426.

Basham, H. G. \& Bateman, D. F. (1975). Killing of plant cells by pectic enzymes: the lack of direct injurious interaction between pectic enzymes and their soluble reaction products and plant cells. Phytopathology 65, 141-153.

BiRnBoIM, H. C. \& DolY, J. (1979). A rapid alkaline extraction procedure for screening recombinant plasmid DNA. Nucleic Acids Research 7, 1513-1523.

Bolivar, F. (1978). Construction and characterization of new cloning vehicles. III. Derivatives of plasmid pBR322 carrying unique EcoRI sites for selection of EcoRI generated recombinant DNA molecules. Gene 4, 121-136.

Bolivar, F., Rodriguez, R. L., Greene, P. J., Betlach, M. C., HeYNEKER, H. L., BoYer, H. W., Crosa, J. H. \& FALKow, S. (1977). Construction and characterization of new cloning vehicles. II. A multipurpose cloning system. Gene 2, 95-113.

BRADFORD, M. M. (1976). A rapid and sensitive method for the quantitation of microgram quantities of protein utilizing the principle of protein-dye binding. Analytical Biochemistry 72, 248-254.

Buddenhagen, I. \& Kelman, A. (1964). Biological and physiological aspects of bacterial wilt caused by Pseudomonas solanacearum. Annual Review of Phytopathology 2, 203-230.

Calesnick, E. J., Hills, C. H. \& Willaman, J. J. (1950). Properties of a commercial fungal pectase preparation. Archives of Biochemistry 29, 432-440.

Collmer, A. (1986). The molecular biology of pectic enzyme production and bacterial soft rot pathogenesis. In Biology and Molecular Biology of Plant Pathogen Interactions, pp. 277-289. Edited by J. A. Barley. New York: Springer.

Collmer, A., Schoedel, C., Roeder, D. L., Ried, J. L. \& Rissler, J. F. (1985). Molecular cloning in Escherichia coli of Erwinia chrysanthemi genes encoding multiple forms of pectate lyase. Journal of Bacteriology 161, 913-920.

Deretic, V., Konyecsni, W. M., Mohr, C. D., Martin, D. W. \& HIBLeR, N. S. (1989). Common denominators of promoter control in Pseudomonas and other bacteria. Biotechnology 7, 1249-1254.

Dingle, J., Reid, W. W. \& Solomons, G. L. (1953). The enzymic degradation of pectin and other polysaccharides. II. Application of the 'cup-plate' assay to the estimation of enzymes. Journal of the Science of Food and Agriculture 4, 149-155.

Drew, H. R., Weeks, J. R. \& Travers, A. A. (1985). Negative supercoiling induces spontaneous unwinding of a bacterial promoter. EMBO Journal 4, 1025-1032.
Hadero, A. \& Crawford, I. P. (1986). Nucleotide sequence of the genes for tryptophan synthase in Pseudomonas aeruginosa. Molecular Biology and Evolution 3, 191-204.

HAWLEY, D. K. \& MCCluRe, W. R. (1983). Compilation and analysis of Escherichia coli promoter DNA sequences. Nucleic Acids Research 11, 2237-2255.

HEPPEL, L. A. (1971). The concept of periplasmic enzymes. In Structure and Functions of Biological Membranes, pp. 223-247. Edited by L. I. Rothfield. New York: Academic Press.

Hildebrand, D. C. (1971). Pectate and pectin gels for differentiation of Pseudomonas sp. and other bacterial plant pathogens. Phytopatho$\log y$ 61, 1430-1436.

Hinton, J. C. D., Gill, D. R., Lalo, D., Plastow, G. S. \& Salmond, G. P. C. (1990). Sequence of the peh gene of Erwinia carotovora: homology between Erwinia and plant enzymes. Molecular Microbiology 4, 1029-1036.

Holloway, B. W. \& Morgan, A. F. (1986). Genome organization in Pseudomonas. Annual Review of Microbiology 40, 79-105.

HUANG, J. \& SCHELL, M. A. (1990). DNA sequence analysis of pglA and mechanism of export of its polygalacturonase product from Pseudomonas solanacearum. Journal of Bacteriology 172, 38793887.

Keen, N. T., Dahlbeck, D., Staskawicz, B. \& Belser, W. (1984). Molecular cloning of pectate lyase genes from Erwinia chrysanthem and their expression in Escherichia coli. Journal of Bacteriology 159 825-831.

Kotoujansky, A., Diolez, A., Boccara, M., Bertheau, Y., ANDro, T. \& COLENO, A. (1985). Molecular cloning of Erwinia chrysanthemi pectinase and cellulase structural genes. EMBO Journal 4, 781-785.

LAEMMLI, U. K. (1970). Cleavage of structural proteins during the assembly of the head of bacteriophage T4. Nature, London 227, 680-685.

LANGE, E. \& KNÖsEL, D. (1970). Zur Bedeutung pektolytischer, cellulolytischer und proteolytischer Enzyme für die Virulenz phytopathogener Bakterien. Phytopathologische Zeitschrift 69, 315329.

Maniatis, T., Fritsch, E. F. \& Sambrook, J. (1982). Molecular Cloning. A Laboratory Manual. Cold Spring Harbor, NY: Cold Spring Harbor Laboratory.

Manulis, S., Kobayashi, D. Y. \& Keen, N. T. (1988). Molecular cloning and sequencing of a pectate lyase gene from Yersinia pseudotuberculosis. Journal of Bacteriology 170, 1825-1830.

MiLlER, J. H. (1972). Experiments in Molecular Genetics. Cold Spring Harbor, NY: Cold Spring Harbor Laboratory.

Needleman, S. B. \& Wunsch, C. D. (1970). A general method applicable to the search for similarities in the amino acid sequence of two proteins. Journal of Molecular Biology 48, 443-453.

Norrander, J., Kempe, T. \& Messing, J. (1983). Construction of improved M13 vectors using oligodeoxynucleotide-directed mutagenesis. Gene 26, 101-106.

O'Callaghan, C. H., Morris, A., Kirby, S. M. \& Shingler, A. H. (1972). Novel method for detection of $\beta$-lactamases by using a chromogenic cephalosporine substrate. Antimicrobial Agents and Chemotherapy 1, 283-288.

OfUYA, C. O. (1984). Physical properties of pectic polysaccharidases. of Pseudomonas solanacearum from Nigeria. Current Microbiology 10, 141-146.

Plastow, G. S. (1988). Molecular cloning and nucleotide sequence of the pectin methyl esterase gene of Erwinia chrysanthemi B374. Molecular Microbiology 2, 247-254.

Ray, J., Knapp, J., Grierson, D., Bird, C. \& SChuch, W. (1988). Identification and sequence determination of a cDNA clone for tomato pectin esterase. European Journal of Biochemistry 174, 119-124.

Reverchon, S., Hugouvieux-Cotte-Pattat, N. \& RobertBAuDOUY, J. (1985). Cloning of genes encoding pectinolytic enzymes from a genomic library of the phytopathogenic bacterium Erwinia chrysanthemi. Gene 35, 121-130.

Rombouts, F. M. \& PILNIK, W. (1986). Pectinases and other cell-wall degrading enzymes of industrial importance. Symbiosis 2, 79-90.

SAITo, H. \& Mrura, K.-I. (1963). Preparation of transforming DNA by phenol treatment. Biochimica et Biophysica Acta 72, 619-629. 
Sanger, F., Nicklen, S. \& Coulson, A. R. (1977). DNA sequencing with chain-terminating inhibitors. Proceedings of the National Academy of Sciences of the United States of America 74, 5463-5467.

SChell, M. A., Rober Ts, D. P. \& DenNy, T. P. (1988). Analysis of the Pseudomonas solanacearum polygalacturonase encoded by $p g l \mathrm{~A}$ and its involvement in phytopathogenicity. Journal of Bacteriology 170, $4501-4508$.

SETH, A. (1984). A new method for linker ligation. Gene Analytical Techniques 1, 99-103.

SHAW, W. V. (1975). Chloramphenicol acetyltransferase from chloramphenicol-resistant bacteria. Methods in Enzymology 43, 737-759.

STEPHENS, G. J. \& WoOD, R. K. S. (1975). Killing of protoplasts by softrot bacteria. Physiological Plant Pathology 5, 165-181.

TABOR, S. \& RichARDSON, C. C. (1985). A bacteriophage T7 RNA polymerase/promoter system for controlled exclusive expression of specific genes. Proceedings of the National Academy of Sciences of the United States of America 82, 1074-1078.

Thuring, R. W. J., Sanders, J. P. M. \& Borst, P. (1975). A freezesqueeze method for recovering large DNA from agarose gels. Analytical Biochemistry 66, 213-220.

VON HEIJNE, G. (1985). Signal sequences. The limits of variation. Journal of Molecular Biology 184, 99-105.

Yanisch-Perron, C., Vieira, J. \& Messing, J. (1985). Improved M13 phage cloning vectors and host strains. Nucleotide sequence of the M13mp18 and pUC19 vectors. Gene 33, 103-119.

ZINK, R. T. \& ChATTERJEe, A. K. (1985). Cloning and expression in Escherichia coli of pectinase genes of Erwinia carotovora subsp. carotovora. Applied and Environmental Microbiology 49, 714-717. 